\title{
CD4 T Cell to Lymphocyte Ratio Measurement
}

National Cancer Institute

\section{Source}

National Cancer Institute. CD4 T Cell to Lymphocyte Ratio Measurement. NCI

Thesaurus. Code C74638.

The determination of the ratio of CD4 T cells compared to lymphocytes present in a sample. The measurement may be expressed as a ratio or percentage. 